\title{
DNA barcode-based survey of Trichoptera in the Crooked River reveals three new species records for British Columbia
}

\author{
Daniel J Erasmus ${ }^{\text {Corresp., }}{ }^{1}$, Emily A Yurkowski ${ }^{1}$, Dezene PW Huber ${ }^{\text {Corresp. } 2}$ \\ 1 Biochemistry and Molecular Biology, University of Northern British Columbia, Prince George, British Columbia, Canada \\ 2 Ecosystem Science and Management Program, University of Northern British Columbia, Prince George, British Columbia, Canada \\ Corresponding Authors: Daniel J Erasmus, Dezene PW Huber \\ Email address: erasmus@unbc.ca, huber@unbc.ca
}

Anthropogenic pressures on aquatic systems have placed a renewed focus on biodiversity of aquatic macroinvertebrates. By combining classical taxonomy and DNA barcoding we identified 39 species of caddisflies from the Crooked River, a unique and sensitive system in the southernmost arctic watershed in British Columbia. Our records include three species never before recorded in British Columbia: Lepidostoma togatum (Lepidostomatidae), Ceraclea annulicornis (Leptoceridae), and possibly Cheumatopsyche harwoodi (Hydropsychidae). Three other specimens may represent new occurrence records and a number of other records seem to be substantial observed geographic range expansions within British Columbia. 
1 DNA barcode-based survey of Trichoptera in the Crooked River reveals three new species

2 records for British Columbia

3 Daniel J. Erasmus ${ }^{1^{*}}$, Emily A.Yurkowski ${ }^{1}$, and Dezene P. W. Huber ${ }^{2 *}$

$4 \quad{ }^{1}$ Biochemistry and Molecular Biology and

$5 \quad{ }^{2}$ Ecosystem Science and Management Program

6 University of Northern British Columbia, Prince George, British Columbia, Canada

7 *Corresponding authors: daniel.erasmus@unbc.ca, huber@unbc.ca

9 Abstract

10 Anthropogenic pressures on aquatic systems have placed a renewed focus on biodiversity of

11 aquatic macroinvertebrates. By combining classical taxonomy and DNA barcoding we identified

1239 species of caddisflies from the Crooked River, a unique and sensitive system in the

13 southernmost arctic watershed in British Columbia. Our records include three species never

14 before recorded in British Columbia: Lepidostoma togatum (Lepidostomatidae), Ceraclea

15 annulicornis (Leptoceridae), and possibly Cheumatopsyche harwoodi (Hydropsychidae). Three

16 other specimens may represent new occurrence records and a number of other records seem to be

17 substantial observed geographic range expansions within British Columbia.

\section{INTRODUCTION}

20 With accelerating anthropogenic climate change there is a renewed interest in assessing

21 biodiversity in freshwater ecosystems (Parmesan 2006). Freshwater ecosystems are especially

22 under cumulative threats with increased demand for fresh water by industrial activities in

23 riparian zones (Meyer et al. 1999). Assessing insect biodiversity is a challenging, but vital, 
24 activity in the face of these changes in order to understand aquatic food webs, ecosystem

25 services, and for use in aquatic environmental monitoring (Burgmer et al. 2007; Dobson and Frid

26 2009; Cairns and Pratt 1993).

27 Trichoptera taxonomy is primarily based on male adult morphology, which often requires

28 experts for definitive identification. Taxonomy of the larvae is complicated and often

29 problematic as it is not always possible to distinguish between species of the same genus

30 (Burington 2011, Ruiter et al 2013). DNA barcoding and the use of sequence databases,

31 combined with classical taxonomy, can help to speed up this process by allowing rapid surveys

32 of novel regions (Ruiter et al 2013, DeSalle et al. 2005, Jinbo et al. 2011, Pauls et al. 2010, Zhou

33 et al 2007). The Barcode Of Life Database (BOLD) currently contains DNA barcodes for more

34 than 260,000 species including $\sim 4555$ Trichoptera species, and facilitates the identification of

35 species based on subunit I of the cytochrome oxidase I (COI) DNA gene. In addition, recent

36 comprehensive work on barcode-assisted Trichoptera taxonomy (Zhou et al. 2009, 2010a,b,

37 2011, 2016) provides a solid foundation for biodiversity surveys of caddisflies in North America.

38 Trichoptera, Ephemeroptera (mayflies), Plecoptera (stoneflies), and often aquatic Diptera (true

39 flies) are used in well-developed protocols as indicators of aquatic ecosystem health (Lenat and

40 Barbour 1994). Due to their taxonomic richness, differential susceptibility to pollutants, and

41 abundance in almost all water bodies worldwide, shifts in their numbers, relative ratios, or

42 taxonomic diversity both temporally and/or geographically are used to observe stability and

43 disturbance of ecosystems (Houghton 2004; Pond 2012). Monitoring work is best accomplished

44 with good information on which species are present. Due to a lack of historical sampling in some

45 areas, managers often must rely on regional (often province- or state-level) checklists that may or

46 may not represent the taxonomic and functional diversity of smaller areas or specific sensitive 
47 systems. The Crooked River (Figure 1) is the southernmost lotic system in British Columbia that

48 ultimately drains into the Arctic Ocean. It flows north from Summit Lake (which is just on the

49 north side of the continental divide) to McLeod Lake, connecting a series of lakes along the way.

50 From there its water flows via other systems to eventually end up in the Williston Reservoir - a

51 massive hydroelectric reservoir in the Rocky Mountain Trench that represents one of the largest

52 anthropogenic landscape modifications on earth.

53 The Crooked River is named for all the oxbows due to its slow meandering flow. This

54 river is also fed by underground springs, such as Livingston Springs in Crooked River Provincial

55 Park. This well-known spring supplies the river with water year round and moderates annual

56 temperature shifts. An extinct volcano (Teapot Mountain) is situated at its headwaters, and likely

57 provides mineral nutrient inputs. As a bona fide spring creek, the Crooked River has a very flat

58 gradient with swamp and marshland along much of its shoreline. During freshet the river floods

59 these marshes bringing more nutrients into the system. These factors result in high productivity

60 and a fairly stable year-round temperature which make the Crooked River unique compared to

61 neighbouring systems. Nearby river systems are more typical of British Columbia - they are best

62 described as oligotrophic freestone rivers that are highly susceptible to drastic changes in

63 discharge from spring freshets and that show considerable annual temperature variation. The

64 watershed has been logged for years resulting in a network of resource roads and bridges. A

65 major highway and a rail line also run along much of its length, and are at times only a few

66 meters from the river's main channel. However, even with its unique nature and high levels of

67 anthropogenic impacts, our searches have revealed no recorded biodiversity surveys on the

68 Crooked River. 
Besides that, to our knowledge no comprehensive recent assessment has been done on

70 Trichoptera in central or northern British Columbia. As the Crooked River is such a unique and

71 nutrient-rich system we questioned whether it may provide habitat to species not yet reported for

72 British Columbia. The aim of this study was to provide a comprehensive list of the Trichoptera

73 biodiversity in a unique and vulnerable river as a baseline for future work and management.

\section{METHODS AND MATERIALS}

We collected specimens on a biweekly basis from eight locations $\left(\mathrm{CR} 2-54.484^{\circ} \mathrm{N}\right.$, -

$122.721^{\circ} \mathrm{W}, \mathrm{CR} 2 \mathrm{~B}-54.484^{\circ} \mathrm{N},-122.721^{\circ} \mathrm{W}, \mathrm{CR} 3-54.643^{\circ} \mathrm{N},-122.743^{\circ} \mathrm{W}, \mathrm{CR} 4-54.388^{\circ} \mathrm{N},-$

$122.633^{\circ} \mathrm{W}, \mathrm{CR} 5-54.478^{\circ} \mathrm{N},-122.719^{\circ} \mathrm{W}, \mathrm{CR} 6-54.328^{\circ} \mathrm{N},-122.669^{\circ} \mathrm{W}, \mathrm{CR} 100 \mathrm{BR}-$

$\left.54.446^{\circ} \mathrm{N},-122.653^{\circ} \mathrm{W}, \mathrm{CR} 108-54.458^{\circ} \mathrm{N},-122.722^{\circ} \mathrm{W}\right)$ along the edge of the Crooked River,

81 British Columbia between May and August 2014 using both hand and kick-net methods. This

82 study focused mainly on larvae to ensure that we collected caddisflies from the Crooked River

83 only and not from nearby water bodies. We completed collections under the British Columbia

84 Ministry of Environment Park Use Permit \#107171 where required. We preserved specimens in

$8580 \%$ ethanol upon collection. We identified all 2204 caddisfly specimens that we collected to the

86 lowest possible taxonomic ranking (genus or family) based on published morphological keys

87 (Wiggins 1977; Clifford 1991; Schmid 1998). We selected morpho-species and 214 specimens

88 were subsequently sent to the Biodiversity Institute of Ontario (BIO) and its Barcode of Life

89 Database (http://www.boldsystems.org) in Guelph, Ontario, to have their barcode region (COI)

90 sequenced for further classification. We received back 185 useable sequences $(>400$ bp., $<5$

91 miscalls, no contamination detected). We vouchered all specimens set for sequencing at the

92 Centre for Biodiversity Genomics at the University of Guelph. Initial species identification was 
93 based on a $650 \mathrm{bp}$ sequence in $\mathrm{CO} 15$ ' region using the BOLD platform with MUSCLE sequence

94 alignments and a Kimura-2-parameter distance model. The data for all collected specimens are

95 available as dataset dx.doi.org/10.5883/DS-CRTRI.

96 Neighbor joining analyses were performed on Cheumatopsyche harwoodi, Lepidostoma

97 togatum and Ceraclea annulicornis specimens from the Crooked River compared to con- and

98 heterospecific sequence data from the Barcode Of Life Database (BOLD). Evolutionary

99 distances were computed using the Kimura 2-parameter method bootstrapped (5000 replications)

100 after a MUSCLE alignment and were visualized in MEGA6.0 (Saitou and Nei, 1987;

101 Felsenstein, 1985; Kimura, 1980; Tamura et al., 2013). We cross-referenced the Crooked River

102 Trichoptera species list that we obtained from analysis of our BOLD data using checklists,

103 museums records and databases from the following: Canadian National Collection of Insect,

104 Arachnids and Nematodes (http://www.canacoll.org/); Strickland Museum at the University of

105 Alberta; Beaty Biodiversity Museum at the University of British Columbia; Electronic Atlas of

106 the Wildlife of British Columbia (http://ibis.geog.ubc.ca/biodiversity/efauna/); Natureserve

107 (http://www.natureserve.org/); Canadensys (http://www.canadensys.net/), Global Biodiversity

108 Information Facility (http://www.gbif.org/); the Royal Ontario Museum, and the Royal British

109 Columbia Museum (http://search-collections.royalbcmuseum.bc.ca/Entomology).

\section{RESULTS \& DISCUSSION}

112 We used morphological keys to identify all 2204 collected specimens to family or genus,

113 after which we used successful barcodes and database searches to deduce the species identities of

114185 individuals based on previous database annotations. In total we detected 41 caddisfly species

115 - found in 20 genera within 11 families - in the Crooked River system (Table 1). All barcode 
116 data are publicly available at BOLD (dx.doi.org/10.5883/DS-CRTRI). Thirty five of the 41

117 species we identified were assigned to known species via database matches using a $2 \%$ threshold

118 for delineating species within Trichoptera, which is considered to be a reliable approach (Zhou et 119 al. 2009). COI sequences of specimens from the Crooked River with DNA sequences matching $12099.67 \%$ and $99.13 \%$ to Lepidostoma cinereum and Neophylax rickeri respectively, were assigned 121 to the aforementioned species.

122 Among the 34 specimens identified to species with $100 \%$ database matches are

123 Cheumatopsyche harwoodi, Lepidostoma togatum and Ceraclea annulicornis, all three are new 124 species records for British Columbia.

125 There are currently six species within the genus Cheumatopsyche known from British

126 Columbia: C. analis, C. campyla, C. gracilis, C. oxa, C. pettiti and C. smithi (

127 http://ibis.geog.ubc.ca/biodiversity/efauna, Cannings 2007). We found a larva of

128 Cheumatopsyche harwoodi (synonym C. enigma Ross, Morse, \& Gordon, 1971) at CR4 on May

$12916^{\text {th }} 2014$. Based on morphological keys we were only able to classify our specimen to genus

130 level. This is not surprising as morphology-based taxonomy of Cheumatopsyche larvae is

131 exceedingly difficult (Wiggins 1996). In some cases C. harwoodi larvae are indistinguishable

132 from other species within the genus (Burington 2011). Based on our phylogenetic tree-based

133 analysis the Crooked River C. harwoodi sequence groups with $C$. harwoodi sequences from

134 Ontario (JF434099, JF434097), New Brunswick (KR146677), and Manitoba (HM102631); and

135 not with any of the known species of Cheumatopsyche in British Columbia (Figure 2). The

136 Crooked River specimen also aligns $100 \%$ with a DNA sequence of C. harwoodi from Alberta

137 (HM102632), but also with a C. gracilis sequence from Wyoming (HQ560573) (Figure 2). 
139 to species of a physical specimen is required - and ideally replicated a number of times.

140 Currently BOLD has 178 barcodes for specimens identified as C. harwoodi and the Crooked

141 River specimen aligns very closely to these with less than $0.6 \%$ difference within the species as a

142 whole, well below the 2\% threshold suggested by Zhou and co-workers in 2009 . There are

143 currently only two barcodes for $C$. gracilis and both these barcodes group with the various $C$.

144 harwoodi sequences. These two C. gracilis specimens are also quite different, with a $1.3 \%$

145 difference based on our analysis. The preponderance of evidence, then, points to one of three

146 possibilities. First, the two $C$. gracilis specimens in BOLD are actually misidentified $C$.

147 harwoodi and our specimen is also C. harwoodi. Second, the specimens represent different

148 species but that difference is not reflected in the DNA barcode. And third, the taxonomic status

149 of both species should be reconsidered as potentially being one species. A more definitive

150 identification might be possible as BOLD is populated with more $C$. gracilis sequences that

151 helps delineate the two species.

152 On 14 July 2014 we found a larva for Lepidostoma togatum \{synonyms L. canadense

153 (Banks, 1899) L. pallidum (Banks, 1897) Mormomyia togatum Hagen, 1861, Pristosilo

154 canadensis Banks, 1899, Silo pallidus Banks, 1897\} at CR3. The DNA sequence of this

155 specimen aligns clearly with L. togatum sequences (Figure 3). Based on museum and database

156 records in Canada L. togatum is known to be present in the Northwest Territories, Alberta and

157 the Maritime Provinces of Canada. Our report is the first for this species west of the Rocky

158 Mountains.

159 On 13 August 2014 we found a specimen of Ceraclea annulicornis $\{($ synonyms:

160 Athripsodes annulicornis (Stephens, 1836), C. futilis (Banks, 1914), C. recurvata (Banks, 1908), 
161 Leptocerus annulicornis Stephens, 1836, L. futilis (Banks, 1914)\} at CR3 (Figure 1). The

162 phylogenetic tree-based analysis using sequences from Manitoba, Ontario, and New Brunswick

163 strongly suggest our specimen is C. annulicornis (Figure 4).

164 We found specimens belonging to three genera that had no significant matches at the

165 species level on either the Barcode of Life Database or at NCBI; therefore we only provide

166 genus-level identifications (Table 1). A specimen we putatively assign as Micrasema had only

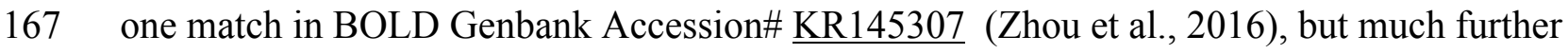

168 south, on southern Vancouver Island. Images of this specimen are publicly available at BOLD

169 (BIOUG18683-F08).

170 A specimen putatively belonging to the genus Hydroptila had a number of $100 \%$ matches

171 to the Crooked River Hydroptila sp. in the BOLD database (Zhou et al., 2016), but none

172 identified to species. Sequence alignments revealed $86 \%$ and $84.74 \%$ similarity to $H$. rono and

173 H. xera respectively; both species are known to be present in British Columbia. The other two

174 known Hydroptila spp. in British Columbia, H. arctia and H. consimilis, are substantially

175 dissimilar from our specimen ( $81 \%$ and $82 \%$ match, respectively). Images of our specimen are

176 publicly available at BOLD (BIOUG18683-A06).

177 A third specimen putatively assigned to Lepidostoma resides in a BIN with only two

178 members (BOLD:ACL5324) -the Crooked River specimen and one other from British Columbia

179 (Genbank Accession \# KX142483). Images of this specimen (adult) are publicly available at

180 BOLD (BIOUG18683-G10).

181 These three specimens are thus most likely also new species records for British

182 Columbia. All known species in British Columbia belonging to Micrasema and Hydroptila have

183 DNA barcodes in BOLD, and ten of the 12 Lepidostoma species known to be in British 
184 Columbia have DNA barcodes in BOLD. Only L. quercina and L. stigma do not, and it is

185 possible that our specimen belongs to one of these two species.

186 The presence of 41 species (20 genera, 11 families) of caddisflies in the Crooked River is

187 comparable to other rivers and regions. For instance collection from the Churchill, Manitoba area

188 - including the Churchill River, tundra ponds, lakes, and small streams - revealed 68 species

189 (Zhou et al. 2009). Collection from the Ochre River, Manitoba revealed 33 species (8 families,

19017 genera) (Cobb and Flannagan 1990). Broad-scale sampling across northern Canada from the

191 Ogilvie Mountains in the Yukon to Goose Bay in Newfoundland revealed 56 species (Cordero et

192 al 2017). To our knowledge, there is no study that provides comprehensive species checklist of

193 caddisflies for a specific tributary in British Columbia to which we could compare our data more

194 regionally.

195 In summary, our assessment of the Trichoptera inhabiting the Crooked River revealed

196 three new species records for British Columbia Lepidostoma togatum, Ceraclea annulicornis

197 andpossibly Cheumatopsyche harwoodi. Our results also suggest at least two, and possibly

198 three, new species records. This baseline biodiversity data is vital for ongoing monitoring and

199 management of this unique and highly impacted system and provides new data for managers and

200 conservationists working in this understudied system.

202 ACKNOWLEDGEMENTS: We thank Claire Shrimpton for assistance in the field. Museum

203 databases were provided by the Beaty Biodiversity Museum at the University of British

204 Columbia (Karen Needham and Chris Ratzlaff), the Royal British Columbia Museum (Claudia

205 Copley and Joel Gibson), the Strickland Museum at the University of Alberta (Bryan Brunet and

206 Felix Sperling), and the Royal Ontario Museum (Doug Currie, Antonia Guidotti, Brad Hubley, 
207 and Brenna Wells). Thank you to the reviewers, especially Dr. Ralph Holzenthal, for their

208 feedback and comments as it improved the manuscript immensely.

209

\section{REFERENCES}

211 Burgmer T., Hillebrand, H., and Pfenninger, M. 2007. Effects of climate-driven temperature

212 changes on the diversity of freshwater macroinvertebrates. Oecologia 151:93-103

213

214 Burrington, Z. L. 2011. Larval Taxonomy, Phylogeny And Historical Biogeography Of The 215 Genus Cheumatopsyche (Trichoptera: Hydropsychidae) In North America. MSc thesis, Clemson 216 University, Clemson SC.

Clifford, H. F. 1991. Aquatic Invertebrates of Alberta. The University of Alberta Press,

223 Edmonton, AB, 314-352.

225 Cobb, D.G., and Flannagan, J. F. 1990. Trichoptera and substrate stability in the Ochre $\underline{\text { River, }}$

226 Manitoba. Hydrobiologica 206: 29-38.

228 Cordero, R. D. Sánchez-Ramírez, S. and Currie, D. C. 2017. DNA barcoding of aquatic insects

229 reveals unforeseen diversity and recurrent population divergence patterns through broad-scale

230 sampling in northern Canada.Polar Biology 40:1687-1695 
233 DeSalle, R., Egan, M. G., and Siddall, M.2005. The unholy trinity: taxonomy, species

234 delimitation and DNA barcoding. Philosophical Transactions of the Royal Society B: Biological 235 Sciences 360: 1905-1916.

237 Dobson, M. and Frid, C. 2009. Rivers. In -Ecology of Aquatic systems. Oxford University Press, 238 Oxford, UK. p. 45-83

240 Felsenstein J. 1985. Confidence limits on phylogenies: An approach using the bootstrap.

241 Evolution 39:783-791.

243 Houghton, D. C. 2004. Biodiversity of Minnesota caddisflies (Insect: Trichoptera): Delineation

244 and characterization of regions. Environmental Monitoring and Assessment 95: 153-181.

246 Jinbo, U. Kato, T. and Motomi ITO. 2011. Current progress in DNA barcoding and future

247 implicationsfor entomology. Entomological Science 14: 107-124

249 Kimura M. 1980. A simple method for estimating evolutionary rate of base substitutions through 250 comparative studies of nucleotide sequences. Journal of Molecular Evolution 16:111-120. 
252 Lenat, D. R., and Barbour, M. T.1994. Using benthic macroinvertebrate community structure for

253 rapid, cost-effective, water quality monitoring: rapid bioassessment. In - Biological monitoring

254 of aquatic systems. Edited by S. L. Loeb and A. Spacie. Lewis Publishers, NY, USA

256 McKay, B. 2000. Crooked River Rats: The Adventures of Pioneer Rivermen. Hancock House

257 Publishers Ltd., Surrey, British Columbia, Canada.

259 Meyer, J., L., Sale, M. J., and Mulholland, P. J. 1999. Impacts of climate change on aquatic 260 ecosystem functioning and health. JAWRA 35: 1373-1386.

262 Parmesan, C. 2006. Ecological and Evolutionary Responses to Recent Climate Change. Annu.

263 Rev. Ecol. Evol. Syst. 37: 637-669.

265 Pauls, S. U. Blahnik, R. J. Zhou, X. Wardwell, C. T. and Holzenthal, R. W. 2010, DNA barcode

266 data confirm new species and reveal cryptic diversity in Chilean Smicridea (Smicridea)

267 (Trichoptera:Hydropsychidae). J. N. Am. Benthol. Soc. 29(3):1058-1074

269 Pond, G. J. 2012. Biodiversity loss in Appalachian headwater streams (Kentucky, USA):

270 Plecoptera and Trichoptera communities. Hydrobiologia 679: 97-117. 
272 Ruiter, D. E. Boyle, E. E. and Zhou X. 2013. DNA barcoding facilitates associations and

273 diagnoses for Trichoptera larvae of the Churchill (Manitoba, Canada) area. BMC Ecology 13: 5

274

275 Saitou N. and Nei M. 1987. The neighbor-joining method: A new method for reconstructing 276 phylogenetic trees. Molecular Biology and Evolution 4:406-425.

278 Schmid, F. 1998. The Insects and Arachnids of Canada. Part 7. Genera of the Trichoptera of 279 Canada and Adjoining or Adjacent United States. NRC Research Press, Ottawa, Ontario, 280 Canada. p.319.

282 Tamura K., Stecher G., Peterson D., Filipski A., and Kumar S. 2013. MEGA6: Molecular

283 Evolutionary Genetics Analysis version 6.0. Molecular Biology and Evolution 30: 2725-2729.

285 Wiggins, G. B. 1977. Larvae of the North American Caddisfly Genera (Trichoptera). University 286 of Toronto Press, Toronto, Ontario, Canada. p. 381.

288 Zhou, X. Kjer, K. M. and Morse, J. C. 2007. Associating larvae and adults of Chinese

289 Hydropsychidae caddisflies (Insecta:Trichoptera) using DNA sequences. J. N. Am. Benthol. Soc.

$290 \quad 26(4): 719-742$

291 
292 Zhou, X, Adamowicz, S. L., Jacobus, L. M., DeWalt, R. E., and Hebert, P. D. N. 2009. Towards

293 a comprehensive barcode library for arctic life - Ephemeroptera, Plecoptera, and Trichoptera of

294 Churchill, Manitoba, Canada. Frontiers in Zoology 6:30.

295

296 Zhou, X., Jacobus, L. M., DeWalt, R. E., Adamowicz, S. J., Hebert, P. D. N. 2010a.

297 Ephemeroptera, Plecoptera, and Trichoptera fauna of Churchill (Manitoba, Canada): insights into 298 biodiversity patterns from DNA barcoding. J. N. Am. Benthol. Soc. 29: 814-837.

300 Zhou, Xin; Jacobus, Luke M.; DeWalt, R. Edward; Adamowicz, Sarah J.; Hebert, Paul D. N.

301 2010b. The Ephemeroptera, Plecoptera, and Trichoptera fauna of Churchill (Manitoba, Canada):

302 insights into biodiversity patterns from DNA barcoding. J. N. Am. Benthol. Soc. 29(3):814-837

304 Zhou, X., Robinson, J.L., Geraci, C.J., Parker, C.R., Flint Jr, O.S., Etnier, D.A., Ruiter, D., 305 DeWalt, R.E., Jacobus, L.M. and Hebert, P.D. 2011. Accelerated construction of a regional 306 DNA-barcode reference library: caddisflies (Trichoptera) in the Great Smoky Mountains 307 National Park. J. N. Am. Benthol. Soc. 30(1), pp.131-162. 
308

309 Zhou, X., Frandsen, P.B., Holzenthal, R.W., Beet, C.R., Bennett, K.R., Blahnik, R.J., Bonada,

310 N., Cartwright, D., Chuluunbat, S., Cocks, G.V. and Collins, G.E., 2016. The Trichoptera

311 barcode initiative: a strategy for generating a species-level Tree of Life. Phil. Trans. R. Soc. B,

$312371(1702)$, p.20160025. 
333

334

335

336

337

338

339

340

341

342

343

344

345

346

347

348

349

350

351

352

353

354

355

356

357

358

359

360

361

362

363

364

365

366

367

368

369

370

371

372

373

374

375

376

377
Figure 1: Map of sampling sites along the Crooked River, British Columbia. CR2: $54.485265^{\circ} \mathrm{N}$, $122.717974^{\circ} \mathrm{W}$; CR2B: $54.484474^{\circ} \mathrm{N},-122.721257^{\circ} \mathrm{W}$; CR3: $54.642963^{\circ} \mathrm{N},-122.743021^{\circ} \mathrm{W}$; CR4:

$54.387709^{\circ} \mathrm{N},-122.633217^{\circ} \mathrm{W}$; CR5: $54.477975^{\circ} \mathrm{N},-122.719000^{\circ} \mathrm{W}$; CR6: $54.328038^{\circ} \mathrm{N},-122.669236^{\circ} \mathrm{W}$; CR100BR: $54.446455^{\circ} \mathrm{N},-122.653129^{\circ} \mathrm{W}$; CR108: $54.458511^{\circ} \mathrm{N},-122.721828^{\circ} \mathrm{W}$.

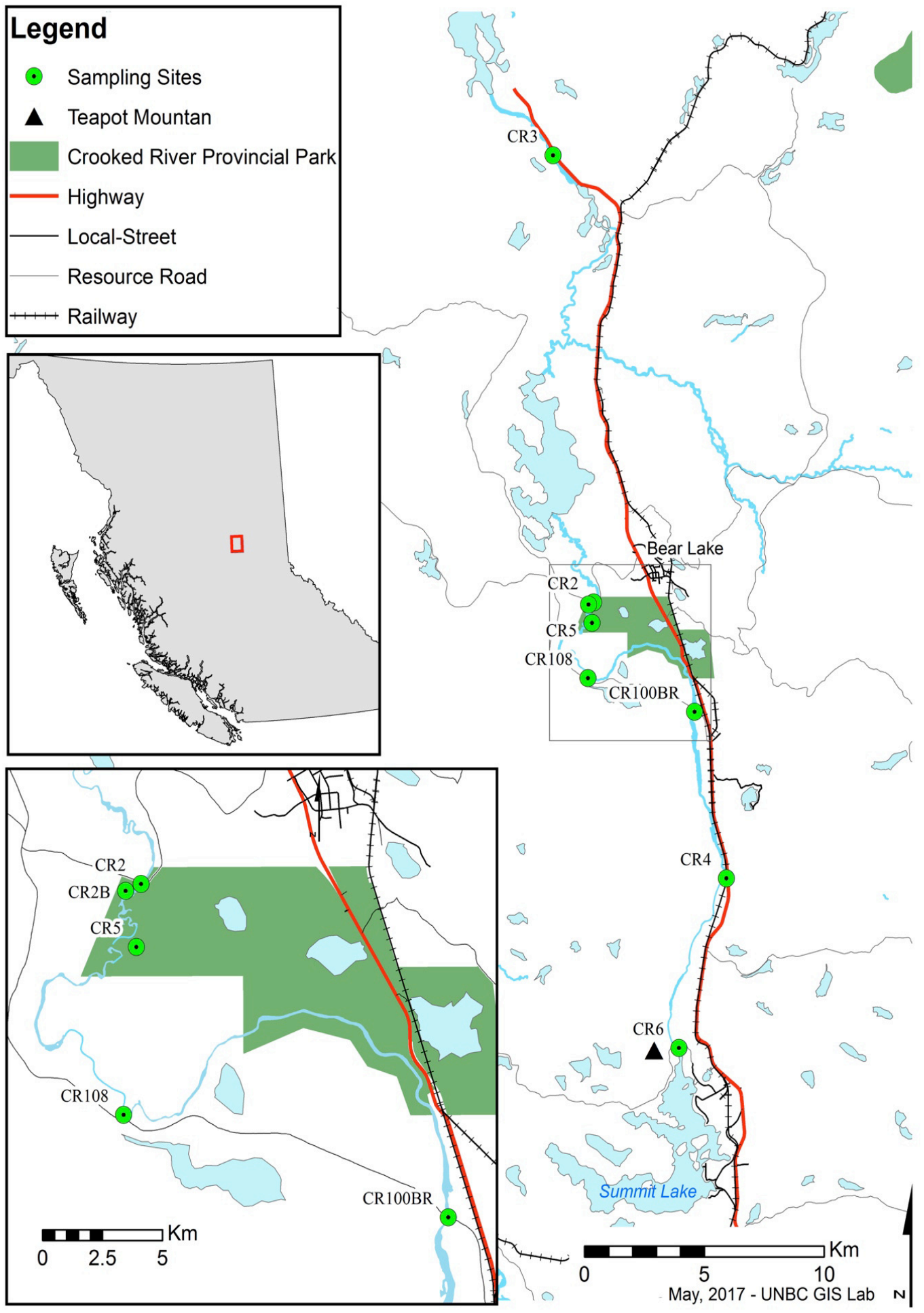


Figure 2: Phylogenetic tree of Cheumatopsyche spp. collected from the Crooked River and congeneric COI-5P DNA sequences of Cheumatopsyche species with DNA barcodes.

381 and the Kimura-2 method to calculate distances. Each species is identified by the geographic

382 region of collection, species, and Genbank accession number for the COI-5P DNA sequence.

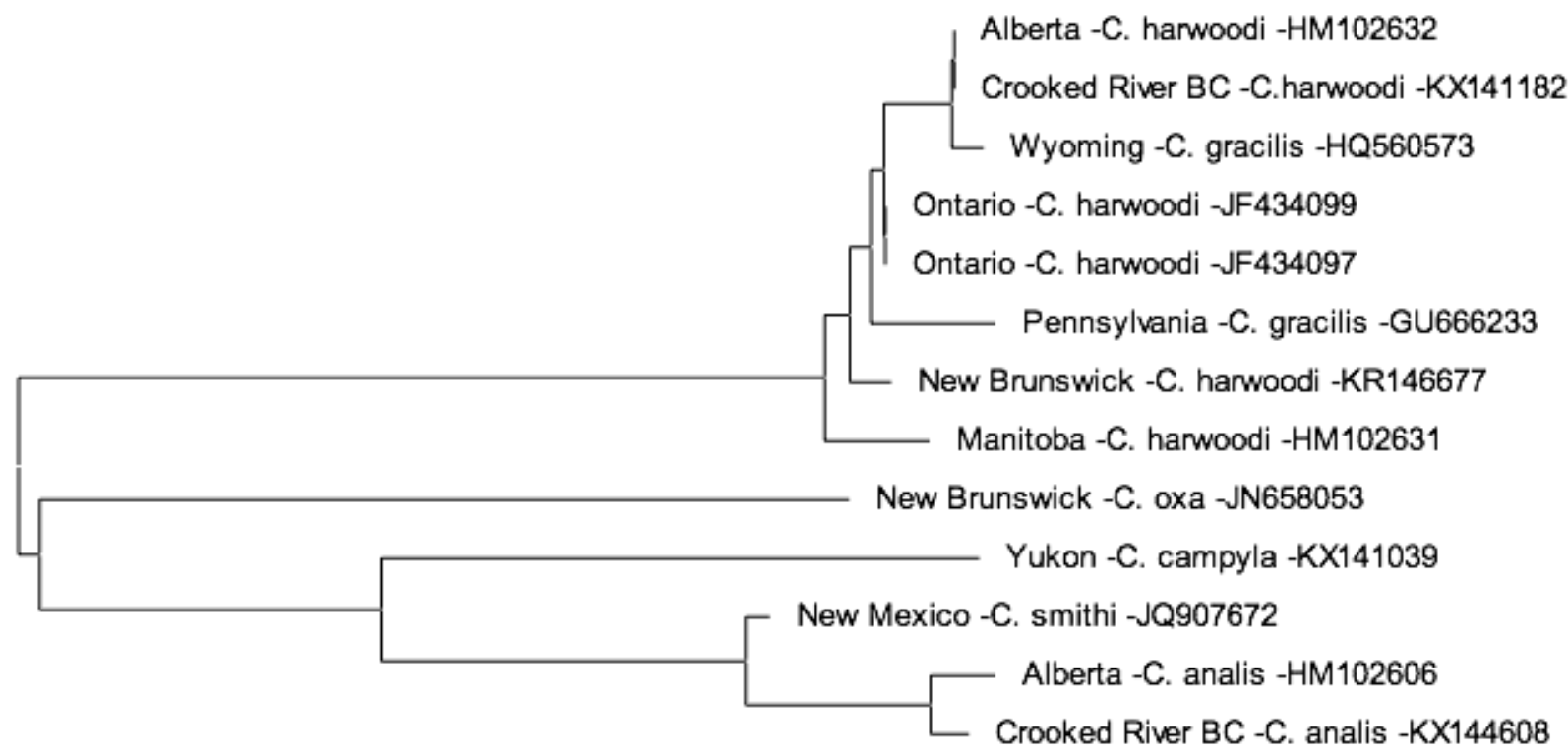

385

386

387 
Figure 3: Phylogenetic tree of Lepidostoma spp. collected from the Crooked River and congeneric COI-5P DNA sequences of Lepidostoma species with DNA barcodes. Evolutionary history is based on the Neighbour-Joining Method bootstrapped (5000 replicates) and the Kimura-2 method to calculate distances. Each species is identified by the geographic region of 393

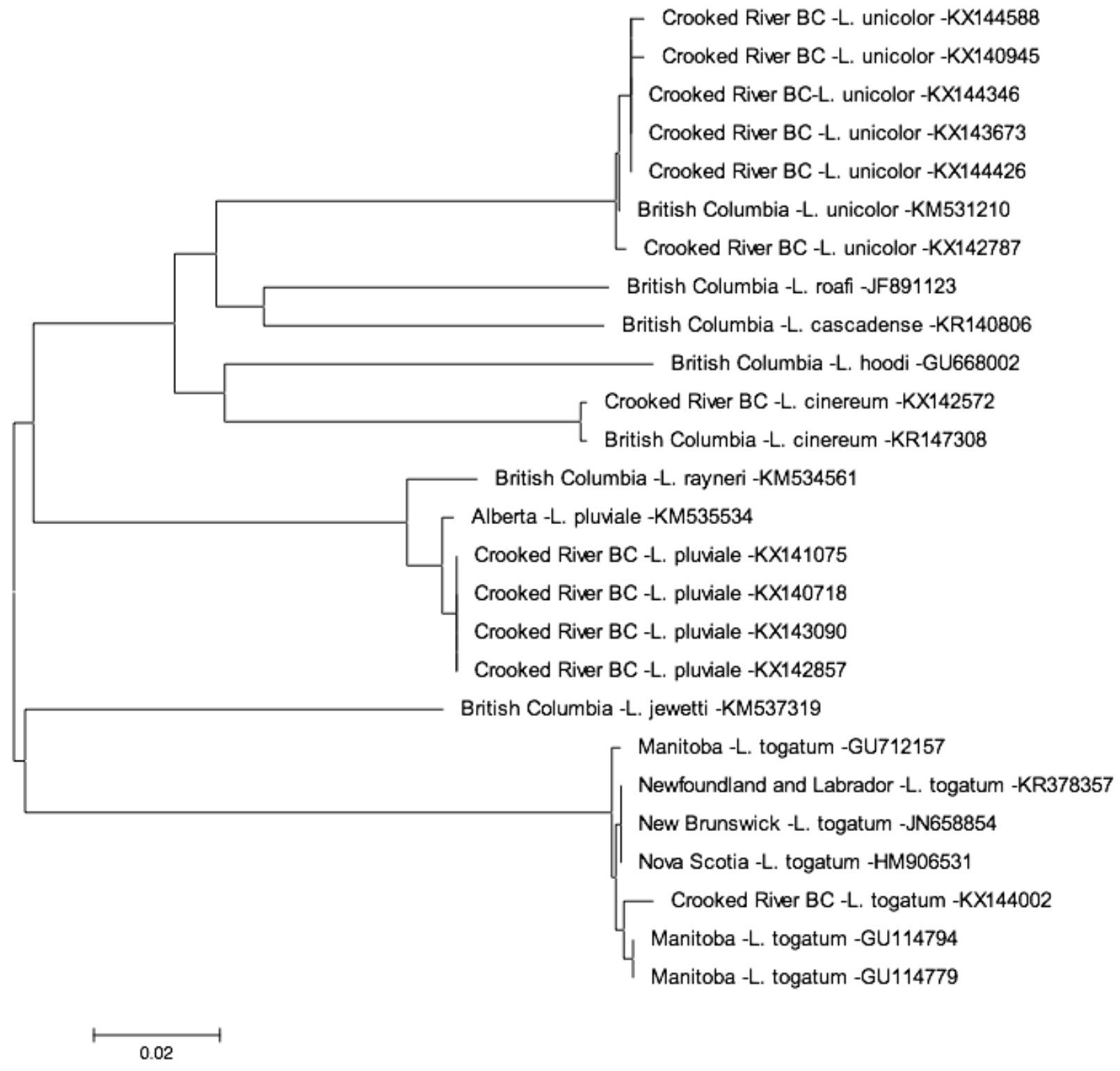


$400 \quad$ Figure 4: . Phylogenetic tree of Ceraclea spp. collected from the Crooked River and congeneric COI-5P DNA sequences of Ceraclea species with DNA barcodes. Evolutionary history is based on the Neighbour-Joining Method bootstrapped (5000 replicates) and the Kimura-2 method to 403 calculate distances. Each species is identified by the geographic region of collection, species, and

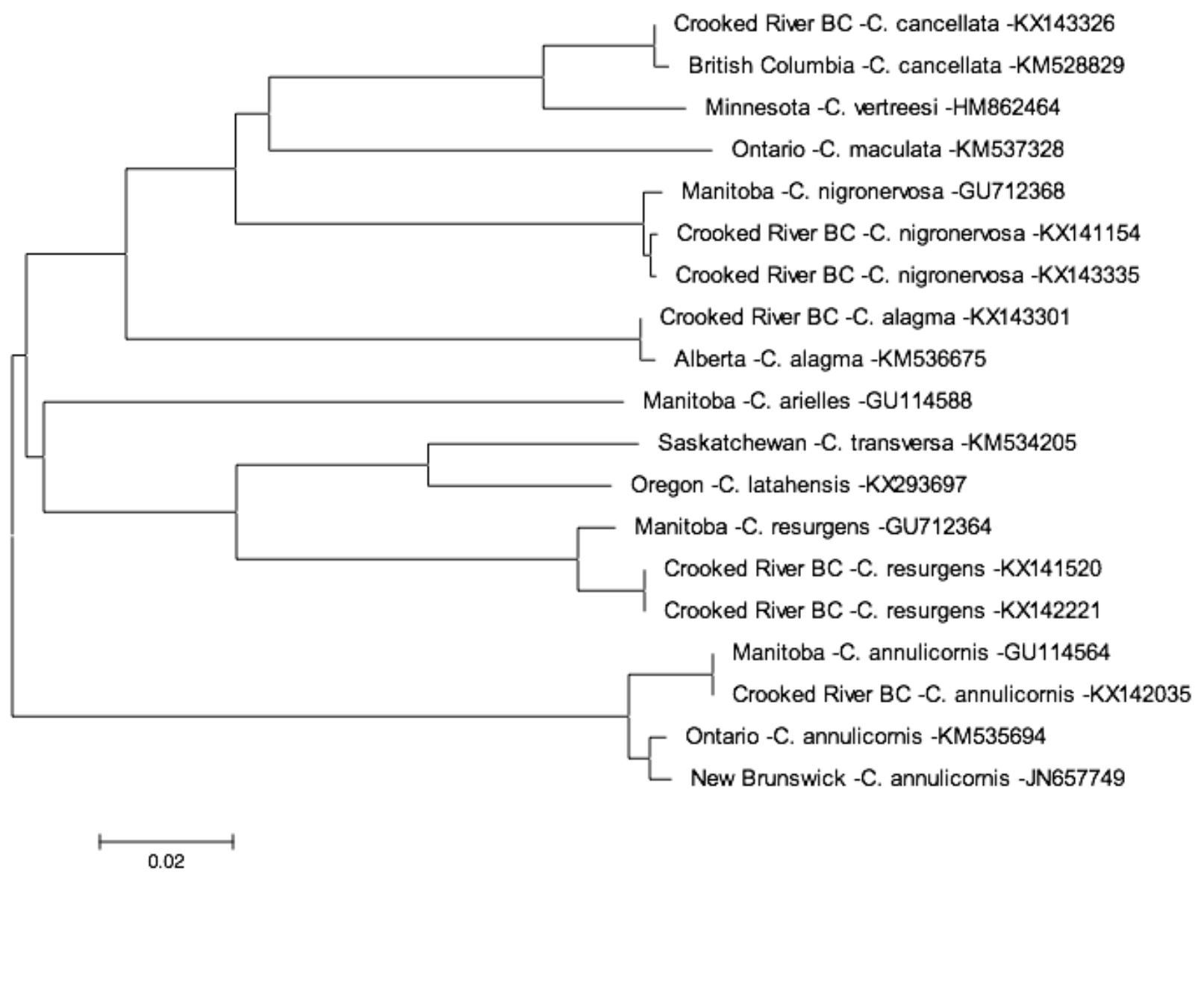


411 Table 1: Trichoptera collected along the Crooked River, British Columbia and associated COI 412 DNA barcode-assigned identifications along with date ranges of collection. Locations of 413 collection sites are given in the footnotes. All sequence data are available in public repositories 414 as listed, and all specimens are vouchered at the University of Guelph - Centre for Biodiversity 415 Genomics. 


\begin{tabular}{|c|c|c|c|c|c|c|c|c|}
\hline Brachycentridae & Brachycentrus & americanus & $\begin{array}{l}\text { BIOUG18684-B11 and } 22 \\
\text { others }\end{array}$ & $\begin{array}{l}\text { BOLD:ABX653 } \\
5\end{array}$ & KX144627 & $\begin{array}{l}\text { CR2, CR2B, CR4, } \\
\text { CR108 }\end{array}$ & $11-J U N$ to $13-A \cup G$ & \\
\hline & & occidentalis & BIOUG18683-H05 and 5 others & $\begin{array}{l}\text { BOLD:AAE028 } \\
1\end{array}$ & KX144012 & CR3, CR100BR & 04-JUN to 13-AUG & \\
\hline & Micrasema & bactro & BIOUG18683-F09.1 & $\begin{array}{l}\text { BOLD:AAC465 } \\
0\end{array}$ & KX143689 & CR4 & 11-JUN & \\
\hline & & sp. & BIOUG18683-F08 & $\begin{array}{l}\text { BOLD:ACC491 } \\
2\end{array}$ & KX142261 & CR2 & 18-JUN & $\begin{array}{l}\text { Potential new } \\
\text { BC record }\end{array}$ \\
\hline \multirow[t]{4}{*}{ Hydropsychidae } & Arctopsyche & grandis & $\begin{array}{l}\text { BIOUG18683-A11.1 and } 6 \\
\text { others }\end{array}$ & $\begin{array}{l}\text { BOLD:AAB304 } \\
9\end{array}$ & KX143192 & CR2, CR108 & 09-JUL to 13-AUG & \\
\hline & $\begin{array}{l}\text { Cheumatopsych } \\
e\end{array}$ & analis & BIOUG18684-B10 & $\begin{array}{l}\text { BOLD:AAA569 } \\
5\end{array}$ & KX144608 & CR100BR & 28-JUL & \\
\hline & & harwoodi & BIOUG18684-B09 & $\begin{array}{l}\text { BOLD:AAA231 } \\
6\end{array}$ & KX141182 & CR4 & 16-MAY & New BC record \\
\hline & & $\mathrm{sp}$. & BIOUG18684-E05 & $\begin{array}{l}\text { BOLD:ACE526 } \\
2\end{array}$ & KX142965 & CR108 & 09-JUL & \\
\hline & & $\mathrm{sp}$. & BIOUG18684-E08 and 4 others & $\begin{array}{l}\text { BOLD:AAA389 } \\
1\end{array}$ & KX142829 & CR3 & 29-JUL to 13-AUG & \\
\hline
\end{tabular}




\begin{tabular}{|c|c|c|c|c|c|c|c|c|}
\hline & Hydropsyche & alhedra & BIOUG18683-H03 and 2 others & $\begin{array}{l}\text { BOLD:AAC165 } \\
0\end{array}$ & KX143172 & CR4, CR108 & 04-JUN to 11-JUN & \\
\hline & & alternans & $\begin{array}{l}\text { BIOUG18683-C12 and } 14 \\
\text { others }\end{array}$ & $\begin{array}{l}\text { BOLD:AAA323 } \\
6\end{array}$ & KX140968 & CR3, CR100BR & $10-J U N$ to $13-A U G$ & \\
\hline & & cockerelli & BIOUG18683-A03 & $\begin{array}{l}\text { BOLD:AAC305 } \\
7\end{array}$ & KX143078 & CR4 & 16-MAY & \\
\hline & & morosa & BIOUG18684-E01 and 5 others & $\begin{array}{l}\text { BOLD:AAA367 } \\
9\end{array}$ & KX143491 & CR3 & 28-JUL & \\
\hline & & slossonae & $\begin{array}{l}\text { BIOUG18684-E06 and } 12 \\
\text { others }\end{array}$ & $\begin{array}{l}\text { BOLD:AAA252 } \\
7\end{array}$ & KX143429 & $\begin{array}{l}\text { CR2, CR4, CR100BR, } \\
\text { CR108 }\end{array}$ & 11-JUN to 13-AUG & \\
\hline \multirow[t]{2}{*}{ Hydroptilidae } & Hydroptila & arctia & BIOUG18683-F10.1 & $\begin{array}{l}\text { BOLD:AAE520 } \\
0\end{array}$ & KX141605 & CR108 & 25-JUN & \\
\hline & & sp. & BIOUG18683-A06 & $\begin{array}{l}\text { BOLD:AAK341 } \\
6\end{array}$ & KX142062 & CR2 & 18-JUN & $\begin{array}{l}\text { Potential new } \\
\mathrm{BC} \text { record }\end{array}$ \\
\hline \multirow[t]{4}{*}{$\begin{array}{l}\text { Lepidostomatida } \\
\text { e }\end{array}$} & Lepidostoma & pluviale & $\begin{array}{l}\text { BIOUG18684-D07.1 and } 3 \\
\text { others }\end{array}$ & $\begin{array}{l}\text { BOLD:ACF229 } \\
5\end{array}$ & KX142857 & CR100BR & 18-JUN to $13-A U G$ & \\
\hline & & sp. & BIOUG18683-G10 & $\begin{array}{l}\text { BOLD:ACL532 } \\
4\end{array}$ & KX144650 & CR2 & 4-AUG & $\begin{array}{l}\text { Potential new } \\
\mathrm{BC} \text { record }\end{array}$ \\
\hline & & togatum & BIOUG18684-D02 & $\begin{array}{l}\text { BOLD:AAA232 } \\
5\end{array}$ & KX144002 & CR3 & 14-JUL & New BC record \\
\hline & & cinereum & $\begin{array}{l}\text { BIOUG18683-C07.1 and } 3 \\
\text { others }\end{array}$ & $\begin{array}{l}\text { BOLD:AAK794 } \\
3\end{array}$ & KX142572 & CR2, CR2B, CR4 & 25-JUN to 4-AUG & \\
\hline
\end{tabular}




\begin{tabular}{|c|c|c|c|c|c|c|c|c|}
\hline & & unicolor & BIOUG18684-H04 and 8 others & $\begin{array}{l}\text { BOLD:AAC592 } \\
3\end{array}$ & KX142875 & CR4, CR108 & 11-JUN to 4-AUG & \\
\hline \multirow[t]{5}{*}{ Leptoceridae } & Ceraclea & alagma & $\begin{array}{l}\text { BIOUG18683-F06 and two } \\
\text { others }\end{array}$ & $\begin{array}{l}\text { BOLD:AAA587 } \\
6\end{array}$ & KX143301 & CR6, CR100BR, CR108 & 16-MAY to 14-JUL & \\
\hline & & annulicornis & BIOUG18683-B02 & $\begin{array}{l}\text { BOLD:AAA542 } \\
9\end{array}$ & KX142035 & CR3 & 13-AUG & New BC record \\
\hline & & cancellata & BIOUG18684-A01 & $\begin{array}{l}\text { BOLD:ABZ071 } \\
0\end{array}$ & KX143326 & CR4 & 4-AUG & \\
\hline & & $\begin{array}{l}\text { nigronervos } \\
a\end{array}$ & BIOUG18683-H09 and 1 other & $\begin{array}{l}\text { BOLD:AAC378 } \\
1\end{array}$ & KX141154 & CR100BR & 10-JUN & \\
\hline & & resurgens & $\begin{array}{l}\text { BIOUG18683-F07.1 and } 2 \\
\text { others }\end{array}$ & $\begin{array}{l}\text { BOLD:ACG970 } \\
4\end{array}$ & KX142221 & CR3 & 14-JUL to $28-J U L$ & \\
\hline \multirow[t]{5}{*}{ Limnephilidae } & $\begin{array}{l}\text { Amphicosmoecu } \\
s\end{array}$ & canax & BIOUG18683-D09 and 5 others & $\begin{array}{l}\text { BOLD:AAE249 } \\
1\end{array}$ & KX143314 & CR2B, CR4, CR100BR & 11-JUN to 9-JUL & \\
\hline & Clistoronia & magnifica & BIOUG18683-F05 and 1 other & $\begin{array}{l}\text { BOLD:AAC184 } \\
8\end{array}$ & KX141495 & CR3, CR4 & 28-JUL to 13-AUG & \\
\hline & Dicosmoecus & atripes & BIOUG18683-G05 and 2 others & $\begin{array}{l}\text { BOLD:AAC504 } \\
5\end{array}$ & KX140940 & CR4 & 11-JUN & \\
\hline & & gilvipes & $\begin{array}{l}\text { BIOUG18684-H07 and six } \\
\text { others }\end{array}$ & BOLD:AAI9526 & KX142636 & CR2B, CR4, CR100BR & 16-MAY to 9-JUL & \\
\hline & Limnephilus & externus & BIOUG18683-F12 and 1 other & $\begin{array}{l}\text { BOLD:AAA280 } \\
3\end{array}$ & KX141731 & CR2B, CR6 & 11-JUN to 18-JUN & \\
\hline
\end{tabular}




\begin{tabular}{|c|c|c|c|c|c|c|c|}
\hline & Onocosmoecus & unicolor & BIOUG18684-H04 and 8 others & $\begin{array}{l}\text { BOLD:AAC592 } \\
3\end{array}$ & KX142875 & CR4, CR108 & 11 -JUN to 4-AUG \\
\hline & Psychoglypha & alascensis & BIOUG18683-G07 and 7 others & $\begin{array}{l}\text { BOLD:ACH027 } \\
8\end{array}$ & KX141905 & CR4, CR5 & 9-MAY to 4-AUG \\
\hline & & subborealis & $\begin{array}{l}\text { BIOUG18683-D11.1 and } 2 \\
\text { others }\end{array}$ & $\begin{array}{l}\text { BOLD:AAE094 } \\
5\end{array}$ & KX144814 & CR4 & 9-JUL to 4-AUG \\
\hline Philopotamidae & Wormaldia & gabriella & BIOUG18684-C03 and 4 others & $\begin{array}{l}\text { BOLD:AAC153 } \\
9\end{array}$ & KX143731 & CR2, CR108 & $21-\mathrm{JUL}$ to $13-\mathrm{AUG}$ \\
\hline Phryganeidae & Agrypnia & improba & BIOUG18683-C01 & $\begin{array}{l}\text { BOLD:ACK004 } \\
4\end{array}$ & KX143489 & CR2 & 13-AUG \\
\hline \multirow[t]{2}{*}{$\begin{array}{l}\text { Polycentropodida } \\
\text { e }\end{array}$} & Neureclipsis & bimaculata & BIOUG18683-A08 and 3 others & $\begin{array}{l}\text { BOLD:AAE268 } \\
3\end{array}$ & KX141945 & CR3 & $14-J U L$ to $28-J U L$ \\
\hline & Plectrocnemia & cinerea & BIOUG18684-A08 & $\begin{array}{l}\text { BOLD:AAA344 } \\
1\end{array}$ & KX141515 & CR6 & 14-JUL \\
\hline \multirow[t]{2}{*}{ Rhyacophilidae } & Rhyacophila & brunnea & $\begin{array}{l}\text { BIOUG18683-B12 and } 11 \\
\text { others }\end{array}$ & $\begin{array}{l}\text { BOLD:AAB308 } \\
8\end{array}$ & KX141430 & CR4, CR100BR, CR108 & 18-JUN to $2-A \cup G$ \\
\hline & & sp. & BIOUG18684-A07 and 3 others & $\begin{array}{l}\text { BOLD:ACL474 } \\
4\end{array}$ & KX140935 & CR2, CR100BR & 13-AUG \\
\hline Uenoidae & Neophylax & rickeri & BIOUG18683-G08 & $\begin{array}{l}\text { BOLD:AAG954 } \\
3\end{array}$ & KX144032 & CR4 & 4-JUN \\
\hline
\end{tabular}

1- determined from morphological keys and BOLD database match. 